\title{
Translacja warunkowana perspektywą odbiorcy jako metoda łączenia dyskursów. Na przykładzie publikacji dotyczących działalności start-upów
}

\author{
Agnieszka Grażul-Luft \\ Mazowiecka Uczelnia Publiczna w Płocku
}

DOI: http://dx.doi.org/10.18778/1733-8069.16.4.03

\section{Słowa kluczowe: analiza dyskursu, dyskurs edukacyjny, translacja warunko- wana perspektywą odbiorcy}

\begin{abstract}
Abstrakt: Translacja warunkowana perspektywą odbiorcy jest niezbędnym warunkiem efektywnego przekazywania wiedzy nowicjuszowi przez eksperta. Skuteczność zależy w dużej mierze od umiejętności balansowania pomiędzy własnymi nawykami komunikacyjnymi eksperta a koniecznością dopasowania się do możliwości odbiorcy. W dyskursie dotyczącym działalności start-upów proces transmisji wiedzy wydaje się bardzo zróżnicowany, między innymi ze względu na poziom przekazywanej wiedzy, formę przekazu czy zróżnicowanie i wymienność uczestników przyjmujących rolę eksperta i nowicjusza. Jednocześnie ze względu na fakt, iż start-up stał się częścią kultury popularnej i budzi duże zainteresowanie, wiedza dotycząca specyfiki start-upów rozpowszechniana jest bardzo intensywnie. Działalność start-upów staje się zatem treścią dyskursywną w dyskursach różnego typu, zarówno specjalistycznych, jak i niespecjalistycznych. Z analizy tekstów wynika, że translacja ze względu na perspektywę odbiorcy, wiążąca się z upraszczaniem treści, staje się metodą tworzenia powiązań między tymi tworzącymi sieć dyskursami.
\end{abstract}

Agnieszka Grażul-Luft, doktor nauk humanistycznych w zakresie językoznawstwa, adiunkt na Wydziale Nauk Humanistycznych i Informatyki Mazowieckiej Uczelni Publicznej w Płocku, obecnie prorektor ds. studenckich i dydaktyki tej Uczelni. Zainteresowania naukowe obejmują m.in.: pragmalingwistykę, słownictwo współczesnej polszczyzny, dyskurs polityczny i medialny, etykę słowa.

\section{Adres kontaktowy:}

Mazowiecka Uczelnia Publiczna w Płocku

Wydział Nauk Humanistycznych i Informatyki

Zakład Nauk o Komunikacji Społecznej i Mediach

Plac Dąbrowskiego 2

09-402 Płock

e-mail: agnieszka.grazul@gmail.com 


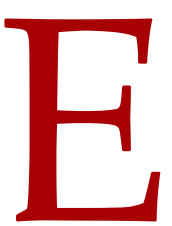

fektywność przekazywania wiedzy nowicjuszowi przez eksperta jest w znacznej mierze zależna od umiejętności skutecznej translacji treści, warunkowanej perspektywą odbiorcy. Dyskurs edukacyjny, rozumiany jako każdy typ praktyki komunikacyjnej związanej z transmisją wiedzy od osoby ją posiadającej (eksperta, nauczyciela) do uczestnika (nowicjusza, ucznia), który jej nie posiada, ale chce ją zdobyć (Skudrzykowa, Warchala 2002; Nocoń 2016), „charakteryzuje napięcie między włączaniem we wspólny horyzont dyskursywny a staraniami o rozumienie nowej wiedzy, między własnymi nawykami dyskursu a koniecznością dopasowania się do możliwości odbiorcy" (Skudrzykowa, Warchala 2002: 279). W dyskursie dotyczącym działalności start-upów, będących formą aktywności biznesowej cieszącej się obecnie dużą popularnością, ten proces transmisji wiedzy wydaje się zróżnicowany, między innymi ze względu na poziom przekazywanej wiedzy, formę przekazu czy odmienność i wymienność uczestników przyjmujących rolę eksperta i nowicjusza. Jednocześnie ze względu na fakt, iż start-up stał się częścią kultury popularnej i budzi duże zainteresowanie, wiedza dotycząca specyfiki start-upów jest intensywnie rozpowszechniana. Działalność start-upową promuje się jako formę aktywności biznesowej nie tylko dobrą dla każdego, ale również istotną dla przyszłości gospodarki. Popularyzacja prowadzi niejednokrotnie do częściowej dezinformacji, wynikającej na przykład z wypaczania podstawowych pojęć i mechanizmów będących wynikiem upraszczania.

Celem niniejszej pracy jest zaprezentowanie sposobów translacji warunkowanej perspektywą odbiorcy na poziomie użycia języka, w związku z transmisją wiedzy, w dyskursie dotyczącym działalności start-upów. Metody translacji zostały wyodrębnio- ne na podstawie analizy tekstów wprowadzających $\mathrm{w}$ tematykę start-upu, przyjmujących często charakter poradnikowy, oraz tekstów mających na celu prezentację działalności lub opis produktów start-upów.

Badania w tym obszarze zostały podjęte ze względu na fakt, iż skuteczna translacja jest warunkiem efektywnego przekazywania wiedzy, a brak precyzji może w konsekwencji przekładać się na niewystarczającą skuteczność działań, a nawet niepowodzenie przy podejmowaniu aktywności biznesowej. Upowszechnianie, przyjmujące formę transmisji wiedzy od eksperta do nowicjusza, wiąże się wobec tego z odpowiedzialnością. Analiza we wskazanym zakresie, poprzez wyodrębnienie sposobów translacji, pozwoli odpowiedzieć na pytanie o różnorodność stosowanych metod. Ponadto wyniki analiz tekstowych posłużą próbie odpowiedzi na pytanie, czy stosowane sposoby translacji mają wpływ na realizację celu komunikacyjnego, jakim jest prawidłowe i skuteczne przekazanie wiedzy nowicjuszowi.

\section{Czym jest start-up?}

Start-up można uznać za formę aktywności biznesowej. W najczęściej przywoływanych definicjach specjalistycznych określa się go jako tymczasową organizację bądź instytucję utworzoną w celu znalezienia właściwego modelu biznesowego lub też tworzenia nowych usług i produktów. Podkreśla się jednocześnie, że tego rodzaju aktywność wiąże się z działaniem w warunkach skrajnej niepewności (Ries 2012; Blank, Dorf 2013). Start-up jest od kilku lat, również na gruncie polskim, intensywnie popularyzowaną formą działania biznesowego, czego dowodem jest między innymi fakt, iż sam internacjonalizm „start-up” z terminologii naukowej, profesjonalnej przeszedł do języka ogólnego (Grażul-Luft 
2019). W minionych kilku latach w Polsce opublikowano kilkadziesiąt książek poradnikowych dotyczących tematyki start-upowej (są to zarówno tłumaczenia prac z zagranicy, jak i publikacje polskich autorów), ukazują się czasopisma branżowe np. „StartUp Magazine”, liczne publikacje internetowe, powstały organizacje pozarządowe (np. Fundacja Startup Poland) wspierające i promujące tę formę aktywności biznesowej. Uznano, że funkcjonowanie start-upów jest istotne dla przyszłości gospodarki, co często podkreślane jest przez rządzących (np. podczas kolejnych edycji Kongresu Impact $^{1}$ ). Aktywność start-upową popularyzują również instytucje państwowe ${ }^{2}$, powstają programy wsparcia dla rozwoju start-upów. Z opublikowanego w 2019 roku raportu Polskiej Agencji Rozwoju Przedsiębiorczości wynika, że choć liczba start-upów funkcjonujących w Polsce jest trudna do podania i nie prowadzi się w tym celu reprezentatywnych badań, szacuje się, że tylko w centrum Polski (z głównymi miastami - Warszawą i Łodzią) funkcjonuje 3-6 tysięcy start-upów (w zależności od przyjętej definicji start-upu) ${ }^{3}$.

Modna jest $\mathrm{w}$ zasadzie nie tylko forma aktywności, ale i sam internacjonalizm „start-up”, którego często się nadużywa i stosuje do określania nowopowstałej firmy każdego typu. Jednym z powodów tego zjawiska jest niewątpliwie fakt, iż start-up stał się elementem kultury popularnej i budzi bardzo pozytywne konotacje. Kojarzony jest z technologiami przyszłości, nieprzeciętnymi ludźmi i szybkim

\footnotetext{
${ }^{1}$ Odbywający się w Krakowie międzynarodowy Kongres Impact jest poświęcony zagadnieniom przyszłości gospodarki i tzw. czwartej rewolucji przemysłowej.

2 Np.: https://www.biznes.gov.pl/pl/publikacje/3303-jak-zalozyc-startup [dostęp 15.07.2020 r.]; https://www.funduszeeuropejskie.gov.pl/strony/wiadomosci/zaloz-start-up-bez-falstartu/ [dostęp 15.07.2020 r.].

3 Zob. https://www.parp.gov.pl/storage/publications/pdf/Startupy-w-Polsce---raport-2019_200117.pdf [dostęp 23.07.2020 r.].
}

sukcesem na wielką skalę. Sztandarowymi przykładami start-upowego osiągnięcia są między innymi Facebook, Uber czy Dropbox.

Popularność start-upu niewątpliwe wiąże się z upowszechnianiem i intensywną promocją ogólnie pojętej przedsiębiorczości. Zakładanie własnej działalności gospodarczej, prowadzenie firmy obecnie uważa się za obszar aktywności dostępny właściwie każdemu, niezależnie od wieku, doświadczenia, wykształcenia, zawodu, zasobów finansowych czy miejsca zamieszkania. Rodzaj inicjatywy, jaka jest start-up, doskonale wpisuje się $\mathrm{w}$ tę tendencję. Dlatego o start-upach mówi się nie tylko w środowiskach biznesowych czy naukowych, ale również w obszarze działalności administracji publicznej, edukacji czy polityki. Internacjonalizm jest bardzo rozpowszechniony również $\mathrm{w}$ dyskursie medialnym (Grażul-Luft 2019). Start-up dawno przekroczył granicę dyskursu specjalistycznego, co z jednej strony było podyktowane potrzebą popularyzacji tej formy aktywności biznesowej, z drugiej zaś zostało niejako wymuszone na twórcach i właścicielach start-upów w związku z koniecznością pozyskiwania inwestorów i klientów.

Niewątpliwie duży wpływ na upowszechnienie idei start-upu miał amerykański serial Dolina Krzemowa ${ }^{4}$. Jego bohaterami są młodzi, ekscentryczni mieszkańcy Doliny Krzemowej, odnoszący spektakularne sukcesy w obszarze nowoczesnych technologii. Jednym z problemów tych twórców start-upu jest brak umiejętności zaprezentowania własnego produktu inwestorom i klientom. Główny bohater (Richard Hendricks), innowator, to stereotypowy, introwertyczny informatyk, który umie posługiwać

\footnotetext{
${ }^{4}$ W oryginale - Sillicon Valley. Serial jest emitowany od 2014 roku i ze względu na jego popularność wyprodukowano już sześć sezonów.
} 
się tylko językiem branżowym, specjalistycznym, a konieczność wystąpień przed ludźmi wzbudza $\mathrm{w}$ nim atak paniki. $\mathrm{W}$ jednym $\mathrm{z}$ odcinków serialu ${ }^{5}$ toczy się następujący dialog:

Scena 1 (główny bohater próbuje wyjaśnić, na czym polega innowacyjna działalność jego firmy Pied Piper):

Prawnik: Czym jest Pied Piper?

Richard Hendricks: Zaczęliśmy jako apka muzyczna.

Prawnik: Fuj!

Richard Hendricks: Ohyda! Ale potem skręciliśmy.

Prawnik: W kierunku?

Richard Hendricks: Mamy dobre rezultaty we wszystkich mediach: audio, wideo, metadane. Choć mieliśmy kłopoty z kodowaniem wideo 3D. Chyba dlatego, że wartość pikseli...

W tym momencie słuchacz zupełnie stracił zainteresowanie opowieścią głównego bohatera.

Scena 2 (Erlich Bachman, współpracownik Hendricksa, świadomy problemów komunikacyjnych kolegi i konsekwencji, do jakich mogą prowadzić w biznesie, osobiście prezentuje działalność Pied Piper potencjalnemu inwestorowi):

Erlich Bachman: Użytkownik chce mieć szybki dostęp do plików na wszystkich urządzeniach. Dlatego chmura jest Świętym Graalem. Dropbox wygrywa, ale jeśli chodzi o audio i wideo, jest to raczej Stopbox. Użytkownicy Pied Pipera mogliby skompresować wszystkie pliki do stopnia, w którym dostęp byłby faktycznie natychmiastowy. My kontrolujemy przepływ, oni korzystają. Oto wizja w głowie Richarda Hendricksa!

Zaprezentowane fragmenty serialowego scenariusza trafnie ilustrują problem będący istotą niniejszej

$\overline{{ }^{5} \text { Sezon } 1 \text {, odcinek } 4 .}$ analizy. Przedstawiona jest $\mathrm{w}$ nich bowiem próba transmisji wiedzy, translacja $\mathrm{w}$ pierwszym przypadku nieudana między innymi właśnie ze względu na nieumiejętność przyjęcia perspektywy odbiorcy. Warto podkreślić, że w serialu precyzyjnie uchwycono realny problem środowiska start-upowego, wynikający w znacznej mierze z niewystarczających kompetencji komunikacyjnych.

\section{Dyskurs - między abstrakcją a konkretem}

Sytuowanie niniejszej analizy w obszarze dyskursu wymaga przybliżeń teoretycznych związanych $\mathrm{z}$ tą kategorią. W pracach dotyczących dyskursu podkreśla się bardzo często dwie zasadnicze cechy, które stają się punktem wyjścia do dalszych rozważań. Zaznacza się, że jest to pojęcie obecne wielu dyscyplinach, zarówno w obszarze nauk humanistycznych, jak i społecznych, oraz że mamy w jego przypadku do czynienia z rozmyciem terminologicznym (Duszak 1998; Wojtak 2001; Poprawa 2012; 2016; Witosz 2012; 2016a; Piekot 2014; Labocha 2016). Podkreśla się też wynikającą z multidyscyplinarności złożoność problemu definiowania tej kategorii. W niniejszym opracowaniu przyjmuję perspektywę lingwistyczną, w szczególności obszar językoznawstwa polonistycznego, w którym wypracowano swoiste rozwiązania definicyjne i metodologiczne dotyczące dyskursu, niepozostające jednak w oderwaniu zarówno od dorobku lingwistów badających inne języki, jak i badaczy innych dyscyplin.

Przyjęcie tego rodzaju ograniczenia nie oznacza jednak, że można mieć w tym przypadku do czynienia $z$ ujęciem jednoznacznym i łatwym do sprecyzowania. Jak pisze Marcin Poprawa, „polskie badania stylistyczne i tekstologiczne nad dyskursem są konsekwencją przeobrażeń metodologicznych w zakresie lingwistyki tekstowej, hermeneutyki 
literackiej teorii intertekstualności oraz pragmalingwistyki" (2012: 81). Od momentu pojawienia się kategorii dyskursu w pracach z zakresu językoznawstwa polonistycznego zarysowywały się niejako dwie ścieżki: ujęcie dyskursu jako wypowiedzi, tekstu w kontekście (Grzegorczykowa 1998; Kawka 1999) oraz traktowanie go jako kategorii z poziomu idealizacji (Grabias 1994; Labocha 1996) (w nawiązaniu do ustaleń zagranicznej lingwistyki, m.in. francuskiej, anglosaskiej i amerykańskiej). Pojawianie się rodzimych definicji też najczęściej nie prowadziło do ukonkretnienia, a tym bardziej do ujednolicenia. Jak pisze Bożena Witosz (2012), jedną z bardziej „wpływowych” definicji stworzył w latach 90. Stanisław Grabias (1994: 231), który określił dyskurs jako „ciąg zachowań mownych, których postać zależy od tego, kto mówi, do kogo, w jakiej sytuacji i w jakim celu". Tę definicję zaczęli przywoływać zarówno badacze traktujący dyskurs jako normę, model zachowań, ci, którzy utożsamiają dyskurs z konkretną interakcją lub szeregiem interakcji, jak i ci, którzy postrzegają kategorię dyskursu jednocześnie na obu tych poziomach.

Literatura zawierająca rozważania teoretyczne na temat dyskursu jest obszerna i dostrzegalne są $\mathrm{w}$ niej między innymi nurty związane $\mathrm{z}$ ujęciem dyskursu w kontekście stylistyki (Witosz 2009a; 2012) czy w odniesieniu do tekstu (Żydek-Bednarczuk 2005; Bartmiński, Niebrzegowska-Bartmińska 2009; Witosz 2009b; Labocha 2016).

Obecnie pojmowanie kategorii dyskursu, choć różni się w szczegółowych ujęciach, przede wszystkim „lokuje się na poziomie idealizacji (mniej istotne jest $\mathrm{w}$ tej chwili strukturowanie tego poziomu, czyli wyróżnienie abstrakcyjnego systemu i sfery indywidualnych wypowiedzi, czy też wprowadzenie między langue i parole poziomu pośredniego w po- staci norm, konwencji, na którym często umieszcza się kategorię dyskursu" (Witosz 2012: 65). Zdaniem Stanisława Gajdy: 17 ,językoznawcze zainteresowanie tekstem/dyskursem stoi więc przed problemem zintegrowania własnych tradycji z nowymi inspiracjami płynącymi w ramach zwrotów językowego i kulturowego z różnych dyscyplin" (2016: 17). Wśród kwestii do podjęcia wymienia on: status dyskursu (empiryczny a idealizacyjny); złożone całościowe struktury językowe (w tym semantyczne, gatunek, styl); systematyzację różnorodności i wielości czynników kontekstowych oraz ich relacji do struktur językowych; typologię dyskursów (Gajda 2016: 17). Piekot (2014: 16) sprowadza wielość rozumienia kategorii dyskursu do następujących wariantów:

- dyskurs jako coś abstrakcyjnego,

- dyskurs jako coś konkretnego:

- coś jednostkowego,

- coś zbiorowego.

Próba pewnego rodzaju okiełznania trudno uchwytnej kategorii, jaką jest dyskurs, prowadzi też do tworzenia typologii. Bożena Witosz (2016b: 2223) posługuje się otwartą listą różnorodnych kryteriów podziału:

- kryterium instytucjonalne/domeny społecznej (dyskursy: akademicki, urzędowy, naukowy, polityczny, edukacyjny, prawniczy, medyczny, Kościoła katolickiego i inne);

- kryterium podmiotowe, wskazujące na uczestników/aktorów dyskursu (dyskursy: gejowski, punkowy, złodziejski, kobiecy i inne);

- kryterium ideologiczne (dyskursy: liberalny, marksistowski, lewicowy, konserwatywny, feministyczny, neofaszystowski, rasistowski, antysemicki, nacjonalistyczny, ekologiczny i inne); 
- kryterium medium przekazu (dyskursy: prasowy, internetowy, telewizyjny, fotografii, malarstwa, tańca, pisma i inne);

- kryterium międzypodmiotowych relacji (dyskursy: patriarchalny, dominacji, koncyliacyjny, wykluczenia, egalitarny, tolerancji i inne);

- kryterium odniesień przedmiotowych, tematu (dyskursy: smoleński, ekologiczny, antyaborcyjny, o in vitro i inne).

Ze względu na przedmiot niniejszej analizy, która jest realizowana $\mathrm{w}$ odniesieniu do tekstów, warto bliżej przyjrzeć się temu aspektowi zagadnienia. Jak pisze Bożena Witosz, „badania nad dyskursem uświadomiły nam, że do kwalifikatorów gatunkowego i stylowego należy dodać jeszcze dyskursywny, tak bowiem jak nie ma tekstu poza gatunkiem i stylem, tak nie ma tekstu poza dyskursem" (2016a: 31). Tekst $\mathrm{w}$ tym ujęciu jest aktualizacją, w tym i konkretyzacją dyskursu. Dyskurs natomiast można konstruować na podstawie analizy tekstów jako jedynego dostępnego empirycznie materiału (Witosz 2016a: 31). Zdaniem Haliny Grzmil-Tylutki dyskurs jest „konsubstancjalnością wielu elementów: podmiotów, warunków kontekstowych, postaw, a także realizujących dyskurs gatunków, nośników itd. (...). Dyskurs jest predestynowany do działania celowego. (...) Namacalnym efektem celowego dyskursywnego działania są teksty, które materializują całą wspomnianą wcześniej konsubstancjalność różnych czynników. Tekst jest zatem ostatecznym produktem działalności dyskursywnej” (2012: 225). „Dyskurs nie jest bowiem bezpośrednio materialnie obecny $\mathrm{w}$ komunikacji językowej - jest uchwytny tylko pośrednio przez teksty i wypowiedzi, które poddajemy obserwacji i analizie z punktu widzenia ich dyskursywności, czyli powiązania z innymi tekstami i wypowiedziami dotyczącymi określonej dziedziny życia społecznego (...). Teksty pisane i zapisane na długo magazynują wiedzę kulturową i tradycję wspólnot dyskursu" (Labocha 2016: 157-158).

Wobec powyższych rozważań przyjmuję, że dyskurs jest kategorią z poziomu idealizacji, jest czymś abstrakcyjnym, zespołem norm i strategii (Labocha 1996: 51; 2008: 60-61), wzorcem kulturowym oraz normą zachowań komunikacyjnych i społecznych, „dzięki którym możliwe jest międzyludzkie porozumiewanie się zarówno $\mathrm{w}$ bezpośrednich interakcjach, to znaczy tu i teraz, jak i poza barierą czasu i przestrzeni. Równocześnie należy widzieć dyskurs jako normę kulturową regulującą sposób wyrażania więzi i poczucia tożsamości członków poszczególnych zespołów ludzkich, tzw. wspólnot dyskursu, jakie wyłaniają się z praktyk społecznych" (Labocha 2016: 158).

\section{Działalność start-upów w sieci dyskursów}

Prezentując wskazaną wyżej listę kryteriów podziału dyskursów, Bożena Witosz (2016b: 22) podkreśla, że na ich podstawie można stworzyć mapę, rodzaj sieci, na której poszczególne odmiany dyskursów byłyby odpowiednio umiejscowione i połączone różnymi liniami z pozostałymi, tworząc sieć przecinających się powiązań. „Trudno bowiem założyć istnienie jakiegokolwiek typu dyskursu, którego nie charakteryzowałyby pozostałe wyznaczniki"'. W przypadku niniejszej analizy za nadrzędne zostaje uznane kryterium tematyczne, jakim staje się start-up. Przyjęcie takiej perspektywy powoduje, że analiza nieuchronnie kieruje się w stronę obszarów wielu typów dyskursów, tworzących sieć powiązań.

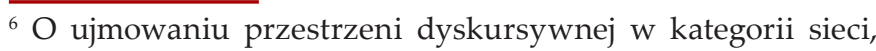
która w odróżnieniu do modelu linearno-hierarchicznego jest modelem symultanicznym, wskazującym na równoczesność i współobecność, pisał również m.in. Stanisław Gajda (2016).
} 
Przyjmując zaprezentowaną wyżej typologię Bożeny Witosz (2016b: 22-23), można dokonać następującego ich uporządkowania:

- kryterium instytucjonalne/domeny społecznej (m.in. dyskurs naukowy, edukacyjny, polityczny, biznesowy, urzędowy);

- kryterium podmiotowe, wskazujące na uczestników/aktorów dyskursu (dyskurs środowisk start-upowych);

- kryterium medium przekazu (dyskursy medialny, prasowy, internetowy);

- kryterium odniesień przedmiotowych, tematu (dyskurs start-upowy/dotyczący działalności start-upów).

Analiza dyskursu wydaje się atrakcyjna, dając możliwość opisania zjawisk komunikacyjnych w perspektywie społeczno-polityczno-kulturowej, poprzez zapożyczanie narzędzi z innych dyscyplin (Poprawa 2012: 82), jednocześnie jednak, ze względu na wynikającą z powyższego złożoność i wszechstronność, wymusza konieczność stosowania ograniczeń. Irena Kamińska-Szmaj (2016: 121-122), definiując dyskurs jako „zbiór tekstów z jego obudową", zaznacza, że choć obudowę należy pojmować szeroko (są to m.in. uwarunkowania historyczne, kulturowe, społeczno-polityczne, prawne, instytucjonalne, świadomość społeczna, wyobrażenia, poglądy, idee, a także zasady, konwencje ich tworzenia i sposoby rozumienia, użyte kody, kanały przekazu, strategie komunikacyjne, interakcje, świadomość gatunkowa, kompetencje i cele nadawcy), gdyż jest to wszystko, co pozwala tekst wszechstronnie zinterpretować, to jednocześnie zaznacza, że "żaden badacz nie jest w stanie, analizując dyskurs, uwzględnić całej obudowy, więc wybiera dla własnych dociekań naukowych tylko - jego zdaniem - elementy najważniejsze". Dlatego też w celu realizacji przyjętych założeń badawczych z właściwości tworzących sieć wskazanych wyżej dyskursów zostaną wyeksponowane tylko wybrane aspekty.

\section{Zjawisko transmisji wiedzy}

Podstawą niniejszego opracowania jest zjawisko translacji warunkowanej perspektywą odbiorcy $\mathrm{w}$ rozumieniu przyjętym w odniesieniu do dyskursu edukacyjnego przez Aldonę Skudrzykową i Jacka Warchalę (2002: 279), którzy postrzegali dyskurs edukacyjny w szerokiej perspektywie jako „każdą formę transmisji wiedzy z perspektywy eksperta do perspektywy nowicjusza", nie łącząc go jedynie z sytuacją szkolną oraz relacją nauczyciel-uczeń. Podkreślali, że proces włączania nowicjusza we wspólnotę dyskursu eksperta zawsze nosi cechy dyskursu edukacyjnego (Skudrzykowa, Warchala 2002: 279).

„Dyskurs edukacyjny charakteryzuje napięcie między włączaniem we wspólny horyzont dyskursywny a staraniami o rozumienie nowej wiedzy, między własnymi nawykami dyskursu a koniecznością dopasowania się do możliwości odbiorcy (...). Dyskurs edukacyjny to w tym sensie rodzaj translacji na różnym poziomie ukonkretniania problemów. (...) Aby dyskurs edukacyjny spełnił wymóg fortunności, translacja musi być warunkowana perspektywą odbiorcy, czyli w obrębie horyzontu danego dyskursu powinna być zakładana perspektywa odbiorcy" (Skudrzykowa, Warchala 2002: 279).

Podobnie ujmuje dyskurs edukacyjny Jolanta Nocoń, traktując go jako „typ praktyki komunikacyjnej, podczas której dochodzi do transferu wiedzy od osoby ją posiadającej (Nauczyciela) do tego uczestnika, który jej nie posiada, a z różnych względów musi lub chce ją posiąść (Ucznia)" (2016: 63), i nie 
ograniczając jedynie do przestrzeni lekcji szkolnej i kształcenia zinstytucjonalizowanego. Warunkami zaistnienia interakcji typu edukacyjnego są: wystąpienie dysproporcji wiedzy między partnerami interakcji (na rzecz potencjalnego Nauczyciela) oraz wejście przez nich w role Nauczyciela i Ucznia (Nocoń 2016: 63).

Jak pisze badaczka, „dyskurs dydaktyczny zapośrednicza treść kształcenia z dyskursu naukowego - w interakcjach edukacyjnych dokonuje się translokacja treści dyskursywnej między tymi dyskursami. Nie jest to jednak proste przeniesienie, konieczne staje się bowiem dostosowanie przekazu do celów edukacji i do możliwości Ucznia (adepta wiedzy, a nie naukowca-specjalisty) (Nocoń 2016: 66). Zdaniem Agaty Małyski (2012: 35), zarówno dyskurs naukowy, jak i dydaktyczny „oznaczają typy dyskursu związane $\mathrm{z}$ naukową sferą życia społecznego, a także zbiory konkretnych dyskursów, występujących $\mathrm{w}$ tej sferze i $\mathrm{w}$ różnej mierze realizujących cechy typowe. Termin dyskurs naukowy funkcjonuje jako hiperonim. Dyskurs naukowy należy do dyskursów wyspecjalizowanych, jest właściwy dla modelu komunikacji, której celem jest zdobywanie nowej wiedzy o świecie, jej opisanie i przekazanie innym".

Zjawisko translacji warunkowanej perspektywą odbiorcy warto też odnieść do kategorii, jaką jest upraszczanie tekstu7, czyli dostosowywanie tekstu do standardu prostego języka, realizowane przy założeniach definicyjnych:

1. prosty język to sposób organizacji tekstu, który zapewnia przeciętnemu obywatelowi szybki dostęp do zawartych w nim informacji (sposób

7 Działanie upowszechniane $\mathrm{w}$ komunikacji społecznej za sprawą ruchu społecznego prostego języka (plain language movement). komunikacji ograniczony jest licznymi regułami, które mają zmniejszyć wieloznaczność, złożoność i redundancję wypowiedzi);

2. standard prostego języka wyznaczają zasady i normy, ujęte często $\mathrm{w}$ formie listy będącej zbiorem wskazówek dla autorów i jednocześnie pozwalającej ocenić przystępność tekstu ewaluatorom;

3. upraszczanie tekstu jest działaniem nieintuicyjnym i nieautorskim, jest procesem, w którym gotowa wypowiedź podlega transformacji, staje się polem negocjacji między autorem i ekspertem;

4. zmiany mogą objąć tylko powierzchniową strukturę przekazu, bez ingerencji $\mathrm{w}$ merytoryczną zawartość (Piekot, Zarzeczny, Moroń 2015).

Idea upraszczania tekstu i metody stosowane w przypadku jej realizacji są $\mathrm{w}$ znacznej mierze zbieżne ze sposobami translacji warunkowanej perspektywą odbiorcy, szczególnie w obszarze transformacji leksykalnych czy interpersonalnych.

W odniesieniu do zaprezentowanych sposobów postrzegania przez badaczy dyskursu naukowego i edukacyjnego przyjmuję za Agatą Małyską (2012), że dyskurs edukacyjny przyswaja pewne treści z dyskursu naukowego, dokonuje się translokacja, podczas której dostosowuje się przekaz do możliwości odbiorcy. Translację warunkowaną perspektywą odbiorcy uznaję zatem za sposób działania, wskutek którego to dostosowanie następuje. Na poziomie użycia języka translacja dokonuje się w wyniku zastosowania określonych zabiegów przy tworzeniu tekstu.

\section{Korpus tekstów poddanych analizie}

W przypadku niniejszej analizy przyjmuję zatem, że mamy do czynienia z dyskursem edukacyjnym, będącym częścią dyskursu naukowego (dyskurs 
specjalistyczny). Jednocześnie jest on jednak częścią dyskursu medialnego i internetowego. Media, ze względu na swą wszechstronność, uznaje się obecnie za najpotężniejszą instytucję edukacyjną (Szkudlarek 1999). „Szczególne miejsce w tej zapośredniczonej z mediów edukacji przypada Internetowi, zwanemu czasem wielkim edukatorem" (Nocoń 2016: 62). W środowisku internetowym role nauczyciela i ucznia zostają uwolnione, przestają być rolami instytucjonalnymi, przyjmowane są najczęściej dobrowolnie, a głównym kryterium ich zaistnienia staje się z jednej strony chęć podzielenia się posiadaną wiedza, a z drugiej - chęć czy potrzeba jej zdobycia (Nocoń 2016: 67).

Maria Wojtak, charakteryzując dyskurs medialny (w tym prasowy), podkreśla jego absorbcyjny charakter - otwartość wielokierunkową na inne dyskursy, wchłanianie ich, czynienie ich przedmiotem prezentacji, a więc także źródłem tematyki, form przekazu i językowych środków. Wskazuje jednocześnie typy absorpcji: przytoczeniową - gdy prasa staje się medium, przekaźnikiem, stając się formą prezentacji dyskursu x (z zachowaniem tożsamości dyskursu), oraz interpretacyjną - kiedy dyskurs $\mathrm{x}$ nie zachowuje pełnej autonomii, a prasa $\mathrm{w}$ istotnym stopniu go przekształca. „Dyskurs prasowy będzie się nam jawił jako dyskurs utkany cytatowo lub transformacyjnie $z$ innych dyskursów. W jego ramach da się wyodrębnić zbiór dyskursów x i dyskursów o x" (Wojtak 2014: 100). W analizowanych materiałach mamy do czynienia przeważnie $\mathrm{z}$ absorpcją interpretacyjną, między innymi w odniesieniu do dyskursu naukowego.

Teksty, które zostały poddane analizie, pochodzą z portali internetowych (nie tylko branżowych), tekstów prasowych (publikowanych w Internecie), profilów społecznościowych, własnych stron internetowych start-upów, blogów. Teksty zostały wyselekcjonowane przy użyciu wyszukiwarki Google (zapytanie: start-up/startup). Ze względu na wczesną fazę upowszechnienia internacjonalizmu na gruncie polskim, najbardziej bogatym źródłem przykładów zastosowań leksemu i jednocześnie bazą tekstów dotyczących tematyki start-upowej jest globalna sieć z narzędziem, jakim jest wyszukiwarka Google. Dlatego została ona wykorzystana jako rozproszony korpus ${ }^{8}$.

Ze względu na fakt, iż wyraz „start-up" na gruncie języka polskiego funkcjonuje zaledwie od kilku lat, nie zastosowano ograniczeń czasowych dla wyszukiwania. Na podstawie wyników z wyszukiwarki (ustawienie: „tylko język polski”) wyselekcjonowano (wg kolejnych wskazań) 150 tekstów dwojakiego rodzaju:

- mających charakter informacyjno-poradnikowy, to znaczy służących wyjaśnieniu, czym jest start-up i podaniu podstawowych informacji, które mogłyby pomóc $\mathrm{w}$ założeniu i rozwijaniu start-upu;

- mających na celu prezentację działalności lub opis produktów start-upów (strony własne start-upów).

Teksty są przede wszystkim pisane, w nielicznych przypadkach mówione (źródło: youtube.com).

W przypadku analizowanych tekstów nadawcami są najczęściej dziennikarze, twórcy/właściciele, pracownicy lub współpracownicy start-upów, przedstawiciele służb prasowych firm i instytucji oraz blogerzy. Odbiorca (zbiorowy) to grupa bar-

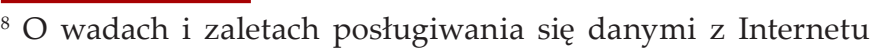
jako korpusem pisali między innymi: Kilgariff, Grefenstette (2003), Piotrowski (2003), Waszakowa (2012).
} 
dzo niejednorodna, którą tworzą prawdopodobnie osoby zainteresowane aktywnością start-upową, użytkownicy mediów, do których treści dotyczące działalności start-upów trafiają w związku z korzystaniem z mediów, jak również szeroko pojęte środowisko start-upów: ich twórcy właściciele, pracownicy, inwestorzy, klienci i inni.

Zarówno nadawcy, jak i odbiorcy bardzo różnią się pod względem doświadczenia, wykształcenia, wieku, typu zainteresowań, pochodzenia czy zasobu wiedzy ekonomicznej i biznesowej. Nadawcami najczęściej nie są profesjonaliści z obszaru biznesu. Wynika z tego, że autorzy tekstów, sami nie będąc specjalistami, czerpią z tekstów profesjonalnych czy naukowych i dokonują transmisji wiedzy (na przykład dziennikarze niespecjalizujący się $\mathrm{w}$ tej tematyce, blogerzy, autorzy tekstów promocyjnych). Stosowane przez nich zabiegi w efekcie prowadzą do transmisji wiedzy naukowej do popularnonaukowej, na przykład w obszarze poradnictwa. Zarysowuje się $w$ takich przy padkach interesujące zjawisko: to nie sam ekspert dokonuje transmisji wiedzy, tylko nadawca (autor tekstu), nie będąc ekspertem, ale czerpiąc z wiedzy eksperta, przyjmuje na siebie rolę tłumacza i dokonuje translacji warunkowanej perspektywą odbiorcy.

\section{Sposoby translacji warunkowanej perspektywą odbiorcy}

Z analizy tekstów wynika, że dostosowywanie przekazywanych treści do możliwości odbiorcy wynikające z konieczności wyjaśnienia zjawisk nowicjuszowi wiąże się z zastosowaniem konkretnych zabiegów na poziomie konstruowania tekstu, które w zależności od własnych kompetencji komunikacyjnych nadawca stosuje w sposób mniej lub bardziej zróżnicowany i świadomy. Zaprezentowane niżej metody należą do powszechnie stosowanych i można je dostrzec w większości analizowanych tekstów.

\section{Wprowadzanie elementów stylu potocznego}

Jedną z metod jest wprowadzanie do wypowiedzi elementów stylu potocznego, odchodzenie od wyznaczników stylu oficjalnego i naukowego, które stoją $\mathrm{w}$ głównej opozycyjnej relacji ze stylem potocznym (Bartmiński 1991), typowych dla określonych sytuacji i form przekazu. W efekcie następuje skrócenie dystansu między nadawcą a odbiorcą i nawiązanie bliższego kontaktu. Bardzo wyrazistą ilustracją tego zjawiska jest stosowanie nieoficjalnych form adresatywnych (zwrotów bezpośrednich) w kontaktach urzędowych, co ilustrują między innymi teksty ze strony Ministerstwa Przedsiębiorczości i Technologii:

Jeśli masz pomysł na biznes i jest on innowacyjny, spróbuj zainteresować nim potencjalnych inwestorów.

(...)

Bądź cierpliwy i konsekwentny w działaniu. Zyski moga pojawić się dopiero po dłuższym okresie. Na początku skup się na pomyśle. (https://www.biznes. gov.pl/pl/publikacje/3303-jak-zalozyc-startup [dostęp 26.05.2019])

Innym sposobem jest stosowanie w tekstach oficjalnych słownictwa potocznego, które również ma na celu skrócenie dystansu, poprzez odejście od oficjalności, na przykład:

Kiepski produkt. (https://sukcespisanyszminka.pl/stworzyc-start-up-wygrac/ [dostęp 26.05.2019])

W niektórych przypadkach elementy stylu potocznego zdają się dominować w całym tekście. 
W połączeniu ze specjalistyczną tematyką i słownictwem, a także bardziej niż w stylu potocznym złożoną strukturą zdań, przynosi to dość zaskakujący efekt:

Start-up to dziwny twór - rzadko kiedy masz fundusze, aby go utrzymać, a on sam generuje dodatkowo koszta, czasem całkiem duże. W czasie swoich ostatnich bojów z kilkoma różnymi projektami (e-apteka, gra sieciowa, serwis kulturalny) utwierdziłem się w przekonaniu, że pieniądze nie są najważniejszą częścią. Nie należy się koncentrować na kasie, planując projekt (zbyt duże przyłożenie wektora „przychodowego" może tak samo dobrze położyć Twój pomysł jak jego brak). Wiem, że wiele osób święcie wierzy w biznesplany - ja nauczyłem się je sporządzać, ale uważam, że są dobre w wypadku, jeśli nigdy wcześniej nie robiłeś żadnego projektu - wtedy BP pozwoli Ci prawidłowo zidentyfikować niebezpieczeństwa projektu.

Najważniejszą częścią Twojego projektu jesteś Ty sam i Twój zespół. Jeśli się uprzecie, to możecie pracować w weekendy, bez kasy, zapychając się ciastkami i popijając wodą z kranu. (https://antyweb.pl/poradnik-dla-startupow-czesc-1-artur-kurasinski/] [dostęp 26.05.2019])

Często słownictwem potocznym zastępuje się profesjonalne, by tekst stał się bardziej przystępny dla odbiorcy. Efekt takiego zabiegu w niektórych przypadkach nie wydaje się szczególnie udany. Przykładem mogą być teksty ze strony internetowej start-upu Insignes Labs, który, jak można przeczytać, ,jest firmą rozwijającą innowacyjne wypełniacze antymikrobiotyczne stosowane do zabezpieczania materiałów przed szkodliwym wpływem niepożądanych bakterii i grzybów, w tym pleśni". W tych pełnych specjalistycznych treści opisach stosuje się jednocześnie słownictwo, takie jak na przykład: "zarazki czy mikroby” (http://insignes-labs.com/pl/ technologia\# [dostęp 26.05.2019]).

W tekstach pojawiają się bardzo często związki frazeologiczne charakterystyczne dla stylu potocznego, na przykład:

biorę to na klatę, zakasać rękawy, w praniu często okaże się (...). (http://startuplife.pl/2018/07/04/dlaczegojako-startupowiec-musisz-tak-czesto-sie-przebierac/ [dostęp 26.05.2019])

Dla osób nie będących na bakier z ekonomią i systemem gospodarczym, przeznaczono także fundusz Venture Capital. (https://europa.eu/youth/pl/article/58/30350_pl [dostęp 26.05.2019])

Masz już po uszy słowa "startup”, odmienianego przez wszystkie przypadki? (http://www.matay.pl/naczym-polega-startup-i-czym-rozni-sie-od-zwyklejfirmy/ [dostęp 26.05.2019])

Nie brak również charakterystycznej dla stylu potocznego obrazowości i silnej ekspresji:

Start-up stał się w ostatnich latach słowem-kluczem, wytrychem do świata pieniędzy i sławy, przedmiotem marzeń milionów ludzi z całego świata. Stał się emanacją starego mitu kariery „od pucybuta do milionera". (https://poradnikprzedsiebiorcy.pl/-czy-start-up-to-przepis-na-sukces [dostęp 26.05.2019])

Im wyżej się wzniesiesz, tym mocniej zaboli upadek. To historia start-upu, który dał się oczarować inwestorom, historia firmy, która rosła zbyt szybko. Historia założyciela, który pozwolił sobie „wjechać na ambicję", który z dnia na dzień musi zwolnić 30 osób. Historia błędów, na których można się wiele nauczyć. Historia, która w gruncie rzeczy dobrze się 
kończy. (https://innpoland.pl/151669,Spowiedz-startupera-jak-rozwijac-startup [dostęp 26.05.2019])

Wydaje się, że konstruowanie tekstu z wykorzystaniem elementów stylu potocznego przez odbiorców odbywa się w sposób bardziej intuicyjny niż uświadomiony. W konsekwencji prowadzi do rażącej niejednorodności stylistycznej, mieszania stylu urzędowego czy naukowego z potocznym, co w efekcie daje wrażenie braku profesjonalizmu.

\section{Przekonywanie, że odbiorca ma do czynienia z czymś tylko z pozoru trudnym}

Autorzy, by oswoić odbiorcę z nową wiedzą, próbują go przekonać, że zagadnienie, które wydaje się skomplikowane i wymagające specjalistycznej wiedzy i szczególnych umiejętności, tylko z pozoru jest trudne. Często tego rodzaju zabiegi stosuje się w przypadku objaśniania anglojęzycznych terminów i skrótów, na przykład:

ROI - pochodzi od angielskich słów Return on Investment, czyli zwrot z inwestycji. Chociaż specjaliści od księgowości mają na ten temat do powiedzenia dużo więcej, to w codziennym zastosowaniu chodzi po prostu o procentową wartość zysku w stosunku do włożonych środków. Im wyższe ROI, tym lepiej dla inwestora. Techniczne objaśnienie tego terminu oferuje niezawodna Wikipedia - po polsku i po angielsku. (https://innpoland.pl/blogi/szymonozimek/117695, slownik-startupow-20terminow-ktore-musisz-znac [dostęp 26.05.2019])

Podstawową optymalizację SEO można wykonać samodzielnie, po przeczytaniu kilku poradników czy z wykorzystaniem dedykowanych wtyczek. (https://smartbees.pl/blog/jak-rozkrecic-startup [dostęp 26.05.2019])
Tego rodzaju metoda, mająca raczej podłoże psychologiczne, przyjmuje różnorodne formy na poziomie realizacji językowej. Jedną z nich jest wprowadzanie pojęć przywołujących narzędzia czy zjawiska, które sugerują, że mamy do czynienia z czymś nieskomplikowanym, do poznania czego wystarczy Wikipedia, kilka poradników albo wtyczek. Stosuje się też wyrażenia wskazujące na prostotę zjawiska, takie jak na przykład „chodzi po prostu o", albo konstrukcje z wykorzystaniem leksemów „wystarczy” (mieć pomysł, zrobić, ściągnąć i in.), "tylko” (wypełnij, sprawdź i in.).

\section{Wyjaśnianie z użyciem przykładów}

Skuteczną metodą translacji jest wyjaśnianie trudnych zagadnień na przykładach:

Chociaż to nie do końca skrót, to bardzo często pojawia się $\mathrm{w}$ tekstach związanych $\mathrm{z}$ tematyką SEO i marketingu internetowego. 301 redirect oznacza dla wyszukiwarek status " moved permanently" czyli tyle, że coś zostało przeniesione na stałe. Na przykład: kiedyś prowadziliśmy stronę pod adresem starastrona.pl, ale ze względu na zmianę koncepcji jej nowy URL to nowawitryna.com. Dzięki 301 redirect Google będzie traktował naszą witrynę pod nowym adresem równie „poważnie” jak traktował starą (jej miejsce $\mathrm{w}$ rankingu zostanie przepisane na nową witrynę). (https://innpoland.pl/ blogi/szymonozimek/117695, slownik-startupow-20terminow-ktore-musisz-znac [dostęp: 26.05.2019])

Podawanie przykładów jest klasyczną metodą stosowaną w dyskursie edukacyjnym. Analiza tekstów prowadzi jednak do konkluzji, że posługują się nią przede wszystkim praktycy, czyli na przykład twórcy czy właściciele start-upów, którzy czerpią przykłady z własnego doświadczenia funkcjonowania 
w branży. Takiego instrumentu nie stosują na przykład autorzy tekstów na stronach instytucji. Dziennikarze korzystają natomiast często $\mathrm{z}$ wiedzy praktyków i ekspertów, przywołując w swych tekstach ich wypowiedzi będące wyjaśnieniem na przykładach.

\section{Rozkładanie na części klasycznych definicji terminów}

$\mathrm{W}$ wielu przypadkach autorzy stosują $\mathrm{w}$ pewnym sensie klasyczną metodę szkolną. Prezentują „podręcznikową" definicję terminu i po kolei objaśniają jej fragmenty. Tak jak w następującym przykładzie, w którym omawia się termin start-up:

Określenie to wykorzystywane jest od zaledwie kilku lat, za sprawą czego nie posiada ściśle ustalonych ram znaczeniowych. Warto jednak powołać się na autorytet Erica Riesa, twórcy koncepcji startupów oraz autora poradnika „Metoda Lean Startup”, powszechnie uznawanego za „biblię dla alumnów startupów”, o czym świadczyć może chociażby obecność na liście bestsellerów New York Timesa. W powyższej publikacji podaje on następujące tłumaczenie: „Startup to ludzka instytucja stworzona z myślą o budowaniu nowych produktów lub usług w warunkach skrajnej niepewności".

Teraz rozwińmy zamysł tej definicji:

- „Startup to ludzka instytucja” - oznacza to, iż jest ona tworzona oraz zarządzana przez zespół ludzi, ułożonych w jakąś hierarchię;

- „stworzona z myślą o budowaniu nowych produktów lub usług" - i tutaj należy zauważyć istotną różnicę między startupem a zwykłą działalnością gospodarczą. Startupem nazwać można wyłącznie przedsięwzięcie na wskroś innowacyjne, nie mające swego identycznego odpowiednika na rynku. Startup może bazować na potrzebach konsumenckich, które dostrzegli już wcześniej inni młodzi przedsiębiorcy, jednak musi podchodzić do nich w sposób odkrywczy, inaczej niż konkurencyjne podmioty - inaczej nie zasługuje on na swoje miano;

- „W warunkach skrajnej niepewności” - kolejna cecha, odróżniająca startup od typowej firmy. Ta ostatnia bazuje zwykle na profesjonalnych wyliczeniach, działa na zbadanym już przez swych poprzedników polu, zapewniającym wystarczający rynek zbytu. Startup opiera się wyłącznie na przypuszczeniach, prawdopodobieństwie, iż dany produkt znajdzie swoich nabywców. Nie istnieją tutaj żadne gwarancje powodzenia - jedyną siłą jest trafiona wizja i zapał do pracy. (https://europa. eu/youth/pl/article/58/30350_pl [dostęp 27.05.2019])

W niektórych tekstach wyjaśnia się termin poprzez odróżnienie, wskazanie cech dystynktywnych:

W ramach definiowania, czym jest startup, wypada również odróżnić go od tradycyjnego przedsiębiorstwa. Aby firma mogła zasługiwać na miano startupu, musi reprezentować dwie cechy - innowacyjność i niepewność. Jeśli Twoja oferta będzie w istocie kalką lub nowszą wersją konkurencji, prawdopodobnie pojęcie startupu nie do końca pasuje do Twojej formy działalności. Twoje usługi lub produkty muszą być nowatorskie, odkrywcze i nieznane dotąd konsumentowi. Weź pod uwagę, na czym polega startup - to działanie eksperymentalne, wymagające odwagi w kreowaniu nowego biznesu i wykorzystujące wyłącznie świeże projekty. Tymczasem, jeśli firma bazuje na doświadczeniu „starszej” konkurencji i poza nowoczesnymi modyfikacjami nie oferuje nic odkrywczego, trudno nazwać ją eksperymentem. (http://www.matay.pl/na-czym-polega-startup-iczym-rozni-sie-od-zwyklej-firmy/ [dostęp 27.05.2019])

Nie brakuje też tekstów, w których próba objaśniania definicji jest tylko pozorna. Nie wnosi treści, 
które mogłyby pomóc w zrozumieniu, a jedynie prowadzi do pewnego rodzaju rozmycia:

Startup można nazwać firmą - eksperymentem. Jej założyciel nie może być pewien sukcesu i powodzenia finansowego, ponieważ próbuje wprowadzić na rynek nowy produkt, usługę lub technologię. Innowacja nie zawsze ma szansę zdobyć uznanie klientów, w związku z czym startupy cechuje brak stabilności i pewności zysku. Oczywiście założyciel młodej firmy nie poddaje się od razu - zanim to nastąpi, będzie próbował zmienić kierunek działania, wypróbuje różne modele biznesu i zainteresuje się nowymi projektami. Wskutek ciągłych zmian startup może przyjąć zupełnie inną formę niż w pierwotnym zamiarze. Zmienność i elastyczność są wpisane w ideę startupu, dlatego funkcjonowanie takiej firmy często przypomina błądzenie po omacku. (http://www.matay.pl/na-czym-polega-startup-i-czym-rozni-sie-odzwyklej-firmy/ [dostęp 27.05.2019])

Mówi się, że w DNA startupu wpisana jest porażka. W odróżnieniu od normalnych firm, które mają już wypracowany stały sposób na zarabianie pieniędzy, startup musi cały czas szukać. W zwykłych przedsiębiorstwach biznes polega na egzekucji wypracowanego już modelu biznesowego. Startup natomiast, żeby taki model wypracować, musi najpierw przetrwać wiele niepowodzeń. Jeżeli marzysz o własnym startupie, to przygotuj się na wiele pułapek i ślepych uliczek. Droga nie będzie łatwa, ale nagroda może być większa niż mógłbyś sobie wyobrazić. (https://biznesflow.pl/czym-jest-startup/ [dostęp 27.05.2019])

Autorzy tekstów często sięgają po tę popularną $\mathrm{w}$ dyskursie edukacyjnym metodę, jednak ze względu na fakt, że do jej skutecznej realizacji potrzebna jest gruntowna naukowa lub profesjonalna wiedza, zabieg ten często jest nieudany i nie może przynieść zakładanego efektu w postaci pozyskania przez adepta nowej wiedzy i zrozumienia zjawiska.

\section{Przykłady uwięzienia w perspektywie nadawcy}

Zdaniem Aldony Skudrzykowej i Jacka Warchali kompetentny nadawca w dyskursie edukacyjnym ma za zadanie „bezustannie schodzić do poziomu ucznia, by następnie móc włączyć go w pożądany dyskurs" (2002: 282). Zagrożeniem dla skuteczności tego zabiegu może być uwięzienie w perspektywie nadawcy, wynikające często $\mathrm{z}$ braku nastawienia interakcyjnego, braku przekładalności perspektyw czy jedynie pozornego włączania we wspólnotę dyskursu (Skudrzykowa, Warchala 2002: 282). Przykładem uwięzienia w perspektywie nadawcy jest objaśnianie zagadnień przy użyciu niezrozumiałego słownictwa i trudnych terminów. Oto fragment rozmowy z twórcą start-upu. Prowadzący czyni wiele starań, by przeciętny odbiorca zrozumiał specyfikę działalności firmy gościa:

Prowadzący: Jesteśmy prostymi ludźmi, przed komputerem nie siedzi też pracownik jakiejś tam wyższej uczelni (...), jego tata prowadzi hurtownię krasnali ogrodowych i on by sobie chciał sprzedawać te krasnale ogrodowe w Internecie. I ty mu dajesz soft, który mu to umożliwia.

Twórca start-upu: Tak. Zgłasza się do nas i my instalujemy mu ten soft na naszej infrastrukturze (...), dajemy mu support, aktualizujemy, dodajemy nowe rzeczy. (https://www.youtube.com/watch?v=JqEdy23TeJs [dostęp 27.05.2019])

Zjawisko uwięzienia w perspektywie nadawcy w przypadku działalności start-upów nabiera nowego wymiaru ze względu na fakt, że ich działalność jest innowacyjna. W związku z tym konieczne jest naprawdę precyzyjne i klarowne objaśnienie, 
czym właściwie jest produkt. Zadanie to okazuje się trudne i często nie przynosi oczekiwanego efektu. Tak jak na przykład w przypadku Abyss Glass - start-upu, który produkuje „lustra interaktywne”. Ich innowacyjność opisana jest na stronie internetowej w następujący sposób:

Lustra interaktywne to innowacyjna przestrzeń, na której zobaczysz znacznie więcej niż swoje odbicie. Lustro naturalnie przyciąga spojrzenie, a wyświetlona na nim treść zostanie zapamiętana na długo. W każdej branży konkurencja staje się obecnie coraz bardziej pomysłowa, a klienci - wymagający. Z myślą o firmach mających ambicje, by wyznaczać nowe trendy, zaprojektowaliśmy interaktywne lustra, które pomogą Ci zdobyć wiodącą pozycję na rynku. (https:// abyssglass.pl/ [dostęp 27.05.2019])

Bardziej szczegółowy, w pewnym sensie techniczny opis też $w$ zasadzie nie bardzo pozwala pojąć, z czym mamy do czynienia:

Abyss Glass to lustro, które posiada spersonalizowany interfejs umożliwiający dopasowanie wyświetlanych treści do potrzeb odbiorcy. Adaptując pomysł wyświetlania obrazu na lustrze, wzbogacono go o rozmaite funkcjonalności. Tak stworzono Abyss Glass - interaktywną powierzchnię reklamową. (...) Zapisane ustawienia będą widoczne od razu na lustrze. Lustra są oparte na systemie boksów. Każda funkcja znajduje się w konkretnym boksie. Klient sam wybiera, które mają się pojawić. Można zmieniać ich położenie, wielkość lub stworzyć własny. W każdym z nich wyświetlają się wybrane informacje: reklama produktu, wizualizacje muzyki, informacje o promocjach, bieżących i nadchodzących eventach lub wydarzenia ze świata. (http://startuppoland.org/startup/abyss-glass/ [dostęp 27.05.2019])
W zasadzie dopiero zdjęcia zamieszczone na stronie internetowej dają możliwość zorientowania się, czym właściwie są innowacyjne lustra Abyss Glass. Wynika z tego, że opis, choć rozbudowany, nie spełnia swojej funkcji informacyjnej.

\section{Podsumowanie}

Ze względu na rozbudowanie sieci dyskursów, które we wspólnym punkcie łączy tematyka start-upowa, w przypadku analizowanych tekstów mamy do czynienia ze znacznym ich zróżnicowaniem stylistycznym. Wynika to prawdopodobnie między innymi ze znacznej różnorodności po stronie nadawców, jak i dużej niedookreśloności po stronie odbiorców. Autorowi bardzo trudno jest choć w niewielkim stopniu doprecyzować, kto będzie czytelnikiem jego tekstu i jaki stan wiedzy i umiejętności będzie reprezentował. Tworzy tekst, który w zależności od sytuacji ma na przykład służyć upowszechnianiu idei, poradnictwu, kreowaniu wizerunku biznesowego, nawiązywaniu kontaktów z klientem czy inwestorem, a język, w zależności od przyjętego celu, staje się narzędziem jego realizacji. Wobec tego translacja warunkowana perspektywą odbiorcy staje się tu mechanizmem wspomagającym, niejako wspierającym proces płynnego przenikania z dyskursu do dyskursu. Analiza tekstów pozwoliła dostrzec pewien schemat postępowania przy tworzeniu tekstów i wyselekcjonować powtarzające się metody. Realizacje tekstowe często nie są jednak udane i wydaje się, że ich wartość informacyjno-edukacyjna nie jest duża. Odbiorca zainteresowany na przykład samym zagadnieniem tworzenia start-upu będzie musiał sięgnąć po bardziej specjalistyczne opracowania, gdyż publikacje poradnikowe, na przykład na stronach instytucji państwowych czy na niespecjalistycznych portalach, 
nie wydają się wystarczająco precyzyjne i profesjonalne. Nie do końca udanej translacji dokonuje się też często $\mathrm{w}$ tekstach prezentujących produkt start-upu. Wydaje się, że powodem jest balansowanie miedzy dwoma skrajnościami: próbuje się dotrzeć jednocześnie i do odbiorcy-niespecjalisty i wytłumaczyć mu często skomplikowane, na przykład technologicznie, zagadnienie w prosty sposób, i do odbiorcy-specjalisty (np. potencjalnego inwestora). W efekcie powstaje tekst niejednorodny, zwykle niemogący zadowolić ni jednego, ni drugiego. I choć zastosowane metody translacji, takie jak na przykład transformacje leksykalne, moż-

\section{Bibliografia}

Bartmiński Jerzy (1991) Styl potoczny jako centrum systemu stylowe języka. „Poradnik Językowy”, z. 1-2, s. 10-22.

Bartmiński Jerzy, Niebrzegowska-Bartmińska Stanisława (2009) Tekstologia. Warszawa: Wydawnictwo Naukowe PWN.

Blank Steve, Dorf Bob (2013) Podręcznik startupu. Budowa wielkiej firmy krok po kroku. Przełożył Bartosz Sałbut. Gliwice: Helion.

Duszak Anna (1998) Tekst, dyskurs, komunikacja międzykulturowa. Warszawa: Wydawnictwo Naukowe PWN.

Gajda Stanisław (2016) Współczesna polska przestrzeń dyskursywna [w:] Bożena Witosz i in., red., Dyskurs i jego odmiany. Katowice: Wydawnictwo Uniwersytetu Śląskiego, s. 15-21.

Grabias Stanisław (1994) Język w zachowaniach społecznych. Lublin: Wydawnictwo Uniwersytetu Marii Curie-Skłodowskiej.

Grażul-Luft Agnieszka (2019) Czym nie jest start-up - o definicjach internacjonalizmu w języku polskim. "Poradnik Językowy”, z. 5, s. 79-88.

Grzegorczykowa Renata (1998) Głos w dyskusji o pojęciu tekstu i dyskursu [w:] Jerzy Bartmiński i in., red., Tekst. Problemy Teoretyczne. Lublin: Wydawnictwo Uniwersytetu Marii Curie-Skłodowskiej, s. 37-44. na uznać za uniwersalne narzędzia wspomagające transmisję wiedzy, to analiza tekstów prowadzi do wniosku, że wykorzystanie tych narzędzi nie jest wcale łatwe i wymaga od autora nie tylko wiedzy specjalistycznej, ale przede wszystkim znacznych kompetencji językowych i komunikacyjnych.

Analiza została przeprowadzona $\mathrm{w}$ ramach projektu pod nazwą "Język jako narzędzie służące wzrostowi efektywności w działalności start-upów - badania pragmalingwistyczne", realizowanego w ramach grantu finansowanego ze środków Gminy Miasta Płocka.
Grzmil-Tylutki Halina (2012) Francuska analiza dyskursu a badania kontrastywne. „Tekst i Dyskurs”, t. 5, s. 223-230.

Kamińska-Szmaj Irena (2016) U źródet politycznego dyskursu dominujacego w czasach PRL [w:] Bożena Witosz i in., red., Dyskurs i jego odmiany. Katowice: Wydawnictwo Uniwersytetu Śląskiego, s. 121-131.

Kawka Maciej (1999) Dyskurs szkolny. Zagadnienia języka. Kraków: Wydawnictwo Naukowe Wyższej Szkoły Pedagogicznej.

Kilgarriff Adam, Grefenstette Gregory (2003) Web as a corpus. „Association for Computational Linguistics" [dostęp 20 lipca 2017 r.]. Dostępny w Internecie: ‘https://www.kilgarriff.co.uk/ Publications/2003-KilgGrefenstette-WACIntro.pdf».

Labocha Janina (1996) Tekst, wypowiedź, dyskurs [w:] Stanisław Gajda i in., red., Styl a tekst. Opole: Wydawnictwo Uniwersytetu Opolskiego, s. 49-53.

Labocha Janina (2008) Tekst, wypowiedź, dyskurs w procesie komunikacji językowej. Kraków: Wydawnictwo Uniwersytetu Jagiellońskiego.

Labocha Janina (2016) Zaolziański dyskurs tożsamości etnicznej [w:] Bożena Witosz i in., red., Dyskurs i jego odmiany. Katowice: Wydawnictwo Uniwersytetu Śląskiego, s. 156-165. 
Małyska Agata (2012) Strategie komunikacyjne we wspótczesnym dyskursie politycznym. Lublin: Wydawnictwo UMCS.

Nocoń Jolanta (2016) Dyskurs edukacyjny w Internecie [w:] Bożena Witosz i in., red., Dyskurs i jego odmiany. Katowice: Wydawnictwo Uniwersytetu Śląskiego, s. 62-70.

Piekot Tomasz (2014) Trzy sposoby rozumienia słowa dyskurs [w:] Irina Uchwanowa-Szmygowa i in., red., Dyskurs w perspektywie akademickiej. Olsztyn: Centrum Badań Europy Wschodniej Uniwersytetu Warmińsko-Mazurskiego w Olsztynie, s. 16.

Piekot Tomasz, Zarzeczny Grzegorz, Moroń Ewelina (2015) Upraszczanie tekstu użytkowego jako (wspót)działanie. Perspektywa prostej polszczyzny [w:] Stanisława Niebrzegowska-Bartmińska i in., red., Działania na tekście. Przekład - redagowanie - ilustrowanie. Lublin: Wydawnictwo UMCS, s. 99-116.

Piotrowski Tadeusz (2003) Internacjonalizm sorki jako element polskiego systemu językowego [w:] Z. Tichá, A. Rangelova, eds., Internacionalizmy v nové slovní zásobě. Sborník př́spěvků z konference Praha, 16-18. června 2003. Prague: Ústav pro jazyk český AV ČR Lexikograficko-terminologické oddělení, s. 184-185.

Poprawa Marcin (2012) Badania dyskursu publicznego w świetle stylistyki polskiej - tradycja, teraźniejszość, perspektywy. „Oblicza Komunikacji", t. 5, s. 77-100.

Poprawa Marcin (2016) Studia nad dyskursem jako humanistyka zintegrowana [w:] Irina Uchwanowa-Szmygowa i in., red., Dyskurs w perspektywie akademickiej. Olsztyn: Centrum Badań Europy Wschodniej Uniwersytetu Warmińsko-Mazurskiego w Olsztynie, s. 22-23.

Ries Eric (2012) Metoda Lean Startup. Wykorzystaj innowacyjne narzędzia i stwórz firmę, która zdobędzie rynek. Przełożył Bartosz Sałbut. Gliwice: Helion.

Skudrzykowa Aldona, Warchala Jacek (2002) Dyskurs edukacyjny a kompetencja interakcyjna. "Studia Pragmalingwistyczne”, t. 3, s. 277-284.
Szkudlarek Tomasz (1999) Media. Szkice z filozofii i pedagogiki dystansu. Kraków: Oficyna Wydawnicza Impuls.

Waszakowa Krystyna (2012) Złożony charakter procesów właczania elementów obcych do języka polskiego (na przykładzie zapożyczenia celebryta) [w:] A. Mikołajczuk, K. Waszakowa, red., Odkrywanie znaczeń w języku [dostęp 20 lipca 2017 r.]. Dostępny w Internecie: http://docplayer.pl/5454270-Zlozony-charakterprocesow-wlaczania-elementow-obcych-do-jezyka-polskiegona-przykladzie-zapozyczenia-celebryta.html».

Witosz Bożena (2009a) Dyskurs i stylistyka. Katowice: Wydawnictwo Uniwersytetu Śląskiego.

Witosz Bożena (2009b) Tekst ali dyskurs w perspektywie polskiej tradycji badań nad tekstem [w:] Zofia Bilut-Homplewicz i in., red., Lingwistyka tekstu w Polsce i w Niemczech. Pojęcia, problemy, perspektywy .Wrocław: Oficyna Wydawnicza Atut, s. 69-80.

Witosz Bożena (2012) Badania nad dyskursem we współczesnym językoznawstwie polonistycznym. „Oblicza Komunikacji”, t. 5, s. 61-76.

Witosz Bożena (2016a) Kategoria dyskursu w polonistycznej edukacji akademickiej [w:] Waldemar Czachur i in., red., Jak analizować dyskurs? Perspektywy dydaktyczne. Kraków: Universitas, s. 19-39.

Witosz Bożena (2016b) Czy potrzebne nam typologie dyskursu [w:] Bożena Witosz i in., red., Dyskurs i jego odmiany. Katowice: Wydawnictwo Uniwersytetu Śląskiego, s. 22-30.

Wojtak Maria (2001) Strategie dyskursywne w pewnym typie tekstu dydaktycznego [w:] Grażyna Habrajska, red., Jezzyk w komunikacji. Łódź: Wydawnictwo Wyższej Szkoły Humanistyczno-Ekonomicznej w Łodzi, s. 168-178.

Wojtak Maria (2014) O gatunkach wypowiedzi i ich prasowych konkretyzacjach. "Językoznawstwo: współczesne badania, problemy i analizy językoznawcze", t. 8, s. 95-105.

Żydek-Bednarczuk Urszula (2005) Wprowadzenie do lingwistycznej analizy tekstu. Kraków: Universitas.

\section{Cytowanie}

Grażul-Luft Agnieszka (2020) Translacja warunkowana perspektywa odbiorcy jako metoda łączenia dyskursów. Na przykładzie publikacji dotyczacych działalności start-upów. „Przegląd Socjologii Jakościowej”, t. 16, nr 4, s. $42-59$ [dostęp dzień, miesiąc, rok]. Dostępny w Internecie: 〈www.przegladsocjologiijakosciowej.org〉. DOI: http://dx.doi.org/10.18778/1733-8069.16.4.03 


\title{
Translation Conditioned by the Recipient's Perspective as a Method of Discourse Combining: The Example of Publications Relating to Start-Up Activities
}

\begin{abstract}
Translation conditioned by the recipient's perspective is a necessary requirement for the effective transfer of knowledge to a novice by an expert. To a great extent, the effectiveness depends on the ability to balance between the expert's own communication habits and the need to adapt to the capabilities of the recipient. In the discourse relating to the activities of start-ups, the process of knowledge transfer seems highly diverse in terms of, among others, the level of the transferred knowledge, the form of communication, or the diversity and interchangeability of the participants who take the role of experts and novices. Simultaneously, in view of the fact that the start-up has become a part of mass culture and tends to arouse much interest, the knowledge about the specifics of start-ups undergoes intensive dissemination. Hence, the activity of start-ups becomes the debatable content of the variety of discourse types, both specialist and non-specialized ones. The analysis of the texts reveals that translation - because of the recipient's perspective associated with the simplification of content - is becoming the method of establishing links between those network-forming discourses.
\end{abstract}

Keywords: discourse analysis, educational discourse, translation conditioned by the recipient's perspective 